\title{
A Tribute to Rick and Debbie Jahnke: From Deep Sea Pore Water to Coastal Permeable Sediments- Contributions that Cover the Oceans
}

\author{
Timothy J. Shaw ${ }^{1} \cdot$ Steve Emerson $^{2} \cdot$ Herbert L. Windom ${ }^{3}$
}

Received: 22 November 2016/ Accepted: 23 November 2016/Published online: 9 December 2016

(C) Springer Science+Business Media Dordrecht 2016

\section{Introduction}

Our hope for this volume is to recognize the many contributions of Rick and Debbie Jahnke through a group of manuscripts that, in part, represent the many areas of research that benefited from their scientific expertise as well as their unselfish organizational support to the community. Rick's early work was in the area of early diagenesis using pore water as indirect observations of the impact of microbial metabolism in sediments as in Jahnke et al. (1982). Fortunately Debbie started having a positive impact on the team early and took the work from indirect observations to direct measurements of metabolism as in Craven et al. (1986). Craven et al. (1986) was also an example of their capacity to think in a full spectrum of spatial scales, from the microscale (e.g., Jahnke 1985; Craven et al. 1986) to the global scale as in Jahnke (1996). Their work also reflected a remarkable ability to master a number of challenging research areas. While most scientists are identified with one research area in one chemical domain, Rick and Debbie ran the spectrum from organic carbon cycling and redox processes (e.g., Smith et al. 1987; Jahnke et al. 1990; Jahnke and Craven 1995; Ingall and Jahnke 1997) to trace element geochemistry (e.g., Bothner et al. 1980; Shaw et al. 1990; King et al. 2000) and from solid phase diagenesis (e.g., Jahnke 1984; Jahnke et al. 1994) to gas solubility (e.g., Weiss et al. 1982).

Rick and Debbie were also pioneers in the recognition of the importance of advective processes in coastal systems (Boudreau et al. 2001; Jahnke et al. 2003; Savidge et al. 2008) and organized the first Gordon Research Conference on permeable sediments. Their broad

Timothy J. Shaw

shaw@mailbox.sc.edu

1 Department of Chemistry and Biochemistry, University of South Carolina, Columbia, SC 29208, USA

2 School of Oceanography, University of Washington, Seattle, WA 98195, USA

3 Skidway Institute of Oceanography, University of Georgia, Savannah, GA 31411, USA 
range of interests required reliable sampling tools, and an important characteristic of Rick and Debbie's work on instruments and sampling platforms was their capacity to find simple solutions to complex problems (e.g., Jahnke 1988; Jahnke and Christiansen 1989; Jahnke and Jahnke 2008). Their capacity to find simple solutions to big problems was quickly recognized and became a hallmark of Rick and Debbie's service work. Rick chaired the Coastal Ocean Processes Program (CoOP) Scientific Steering Committee 2000-2009 and was Interim Program Director for the OOI Program Office. While Rick got the titles, we all know that Debbie did the lion's share of the behind-the-scenes work. We hope the volume serves as recognition of the unselfish service and remarkable research contributions of Rick and Debbie Jahnke.

\section{Perspectives}

\subsection{Rick and Debbie at Scripps Institution of Oceanography, 1981-1987, by Timothy Shaw}

I was fortunate to have the opportunity to work with Rick and Debbie when I was a graduate student at Scripps and then continue the relationship during their time at SkIO. Rick and I started at Scripps at about the same time, when he joined Ray Weiss' group as a postdoc and I was learning pore water chemistry in Joris Gieskes' group. When my interests became focused on near-surface sediments in the Southern California Borderlands, Joris suggested that I talk to Rick about joining some of the ongoing MANOP cruises. I had already heard from fellow students that not all scientists were as easygoing as Joris so it was with some trepidation that I approached Rick with a request to dead head on one of the MANOP cruises. The SIO MANOP team at the time was under tremendous pressure to get an over budget and over engineered instrument to work reliably, and the problems had been tossed in Rick's lap. The best I hoped for was a bunk, what I got was a long-term collaboration and friendship with the Rick and Debbie.

The problems with the MANOP lander could have been a career stopper for Rick. The lander was not producing data, the project was not producing papers, the senior scientists who were dependent on the lander were frustrated, and the head of NSF Chemical Oceanography at the time was losing patience. The atmosphere on the ship during cruises was reminiscent of the Hollywood version of "Mutiny on the Bounty," with the angry crew played by senior scientists. Rick was in the perfect position to play the role of scapegoat for the project, but he never seemed worried. Rick had two things going for him, he started the slow process of simplifying troublesome parts of the lander operation and he had begun collaboration with the Food-Chain group at Scripps that would become a lifelong collaboration with Debbie. So bit-by-bit the lander became a working instrument. The elaborate pressure-sensitive deployment release mechanism was replaced by a simple quick release operated by a release lanyard, the deployments using deck-mounted multispeed sailing winches were accomplished with tag lines, and finally the pump system for sample collection was replaced by simple spring loaded syringes. The instrument went from being an oversized and temperamental deep-sea Dalek to a nice reliable $R 2 D 2$. While this metamorphosis was taking place, Rick and Debbie were getting papers out and quietly becoming a critical part of the sediment biogeochemistry program at Scripps.

Rick and Debbie became central to a number of collaborations in the Scripps community; bringing groups together that might have never collaborated were in not for the 
breadth of their interests. As their collaborators and friends know, the fun and reward of working (and playing) with them is a product of their very different approaches to all of their undertakings. While Rick was the chief scientist who happily worked around the ship whistling the tune to "If I Only Had a Brain," Debbie was quietly keeping the operation running smoothly. From my perspective as a graduate student, Rick brought a playfulness and joy to research that kept it fun and exciting and Debbie was the den mother who made sure the work got done well and everyone was OK. When it was crunch time and the seas got rough, actually and metaphorically, Debbie was the calm voice of reassurance that seemed to always have everyone's back. The reality was that for students, collaborators and later for the larger community, Rick and Debbie had everyone's back. Rick and Debbie made it all look so easy that the extent and importance of their contributions to the Scripps community and the oceanographic community as a whole was not always recognized. I hope the volume will help remind us how much fun and rewarding good research can be when you get to work with folks like Rick and Debbie.

\subsection{Rick in Graduate School and Beyond by Steven Emerson}

Richard Jahnke began his work as an Oceanographer in the late 1970s as a graduate student of Roy Carpenter in the Department of Oceanography at the University of Washington. One of the best things I did as a young Research Professor shortly after I arrived at UW in 1977 was to entice Rick to study early organic matter diagenesis in deep-ocean sediments with me in the NSF-Manganese Nodule Project. He got a Master's degree with Roy, and then we embarked on the study of chemical fluxes at the deep-sea, sediment-seawater interface. This meant, partly, that we spent months of time at sea in the tropical ocean extracting sediment pore waters from cores inside the refer van (at $\sim 4{ }^{\circ} \mathrm{C}$ ) between stations while our fellow scientists played Hacky Sack on the fantail of the ship. It was very hard, uncomfortable work, but Rick and I got through it and published some papers that were innovative at that time. Ultimately, he would become one of the world's foremost experts in the study of marine sediment-seawater exchange. After he got a PhD focusing on the formation of phosphorites, he took a postdoc at Scripps Institution of Oceanography where he continued to study sediment-seawater chemical exchange and would eventually take over the Scripps MANOP Benthic Lander Project. Rick was able to modify an overdesigned benthic lander and turn it into the classic instrument for measuring reliable chemical fluxes in the deep sea. He would continue this type of research, including a focus on near-shore benthic fluxes, during nearly his entire 20-year career at Skidaway Institute of Oceanography.

Rick's contributions to the study of ocean-sediment exchange processes and sediment diagenesis have been fundamental and lasting. He showed the mechanisms for authigenic phosphorite formation and did the best early work on understanding deep-sea sediment denitrification. He and my group at UW had conflicting evidence for the role of organic matter diagenesis on the burial of $\mathrm{CaCO}_{3}$ : His benthic flux measurements showed little effect and our microelectrode pore water measurements indicated that it must be there. The debate never became acrimonious, and I don't think it has ever been truly resolved. After Rick moved much of his research to nearshore environments where sediments often "see the light," he made seminal contributions to understanding the role of benthic fluxes in the carbon cycle of coastal environments.

While I was Rick's PhD advisor, we were only about 5 years apart in age. We both grew up in the Midwest and saw many aspects of the world in a similar light. I was amazingly lucky to be able to work with such a talented researcher at an early period in my career. I 
didn't really have to do much. Rick is motivated and smart, with a strong work ethic, and possesses a pleasant, winning personality. He is like a big teddy bear. My job as his advisor was to help define a research project, entice him to accompany me on deep-sea research cruises, and then to stay out of the way. It was a pleasant, enlightening experience for me to work with Rick early in his career, and it has been a joy and an honor to know him as a colleague and friend.

\subsection{Rick and Debbie During Their Time at the Skidaway Institute of Oceanography (1987-2008) by Herbert Windom}

During 1986, the Skidaway Institute of Oceanography (SkIO) initiated a search for a marine organic geochemist. Dave Menzel, our director at the time, had met and talked with Stuart Wakeham, who was a Postdoc at Woods Hole, about coming to Savannah, so the job description was "wired," basically, for Stuart. I chaired the search committee and we advertised the job reasonably widely thinking it would be straightforward. Then we received an application from Rick Jahnke who was at the time an Assistant Research Geochemist at Scripps. Rick was not on our radar, but our faculty knew of him and held him in high regard. We figured that he was "testing the waters" as a means of leveraging a more secure position at Scripps. Given his resume and our familiarity with his work, we, however, thought it would be money well spent just to get him to Skidaway to have a look around. We had no expectations that he would be seriously interested.

During his visit, he and I had a frank discussion about his intentions. I told him that we were surprised that he would really consider leaving SIO to come to SkIO since he was a major part of the team responsible for the operation and application of bottom landers to seafloor research there. He, however, was very open and honest and explained that he felt his contributions to research at Scripps was being overlooked and viewed the position at SkIO to be a good career move and that he was not interested in using a job offer as leverage to stay in La Jolla. He said he would seriously consider a move to Skidaway if offered the job.

We made the job offer and were pleasantly surprised that he accepted it even though Scripps made a counter offer. As Rick explained it, by that time he had lost his emotional attachment to the place. Rick arrived in July 1987 and brought along a bonus in the form of Debbie Craven, his technician. It turned out that Debbie was more than a super technician. From the very start, we could see that Debbie and Rick were not only an efficient and effective research team but were committed and supportive of each other in every way (and still are).

They hit the ground running at Skidaway. Rick continued his work in developing devices for in situ seabed sampling and analysis, and it was at SkIO where he made his major contributions to the understanding of geochemical processes at the seafloor. His research on carbon burial in marine sediments, during his time at SkIO, provided a major contribution to the understanding of the global carbon budget (as you will read in more detail elsewhere in this volume). This led to his involvement in the early stages of JGOFS. Other papers in this volume will delve into more detail about his service to the broader community.

At SkIO, Rick turned more attention to the coastal ocean, focusing on processes such as benthic primary production and nutrient exchange on continental shelves. During 1999 he was appointed Chair of the Coastal Oceans Processes (CoOP) NSF Program, Scientific Steering Committee. He continued in this position during his tenure at SkIO. An example of Rick and Debbie's strong teamwork is their collaboration in CoOP where Debbie 
assumed the responsibility of editor of the CoOP Newsletter while Rick provided the leadership. It turns out that Debbie is an excellent scientific editors and has had a great deal to do with Rick's successful communication of his research (I am sure that I would get no argument from Rick on this point).

Perhaps motivated by institutional pride, I point out that Rick solidified the scientific reputation of SkIO during his time there. His research here was generally collaborative with researcher all over the world as reflected in his publications (dominantly multiauthored). Likewise, he served in various capacities supporting the activities of many important national and international organizations that have led the way in important areas of marine science. Although Rick's science and service have a significant multi-organizational flavor, he still had a strong commitment to SkIO as did Debbie. Rick was a driving force in the development of collaborative research efforts among the faculty. This is also reflected in his publications, which include coauthored papers with virtually every faculty member at SkIO during his tenure. I was a coauthor on several of Rick's publications and toward the end of his tenure here, he and I collaborated on our first venture into the investigation of significance of groundwater discharge to the coastal ocean. Debbie likewise coauthored papers with members of the faculty other than Rick but was happy to stay out of the "spotlight" when it came to authorship although she often contributed significantly. She was also a wonderful proof reader/editor of institutional publications and many of us took advantage of this expertise when putting together our own manuscripts.

Rick was a major force in getting SkIO more involved in formalized educational activities. While most of the faculty had, historically, attracted graduate students ad hoc, Rick helped to organize summer courses and student visits to attract them to Skidaway. Early on, a series of "distance learning" courses were developed using satellite transmission. Rick was a major contributor to this approach and curriculum development using it.

As described above, the Rick/Debbie team operated with amazing efficiency in both research and science program management. In my opinion, however, their teamwork in local institutional projects was where this synergy was most effective. When the Institute began to engage more formally in educational activities, with considerable input from Rick, it became apparent that we were in need of adequate housing to accommodate increased numbers of students for longer periods. When the institute was founded in 1967, 680 acres of land on Skidway Island was donated by the Roebling family (of Roebling wire/Brooklyn Bridge fame) to accommodate the Institute. Along with the land, the institute inherited two existing docks, a barge that brought material to the island (the bridge to the island was completed in 1970), a shop, a show barn (for the Roebling's' prized Black Angus bulls) and several small houses/apartments that had been used by workers on the Roebling estate. A couple of the old houses could be used, after some rehabbing, for visiting scientists but not much thought was given to any long-term housing plan. Moreover, graduate students had to find housing off island. As visitors and students increased in the 1980s, the housing problem needed to be addressed.

Somehow, Debbie was coerced into taking on the job of improving housing on campus. This, though, would consume considerable time (beyond the normal working day) for the remainder of her time at SkIO. It started with the barn. The barn, because of its useful open space, provided a staging area for the bottom landers prior to cruises and, consequently, was where Debbie and Rick spent a fair amount of time. Always recognizing opportunities, she noticed that an apartment connected to the barn could be renovated into a habitable space. As with everything in which she got involved, Debbie totally committed herself to the task. She was still running Rick's lab, but multi-tasking...no problem. 
From then on, Debbie took the lead in acquiring and improving housing at SkIO. Initially, Debbie oversaw the remodeling of the original houses on campus (a duplex and a home, previously used as a residence for Roebling's veterinarian) and creating a communal laundry room for campus residents (a place where Debbie spent a lot of volunteer hours cleaning sheets and towels for visitor housing). The funds for these renovations were obtained through a NSF (FSML) proposal written by Debbie. Subsequently, two additional NSF proposals (also shepherded by Debbie) resulted in grants to build the "Quadraplex", in 1999, to accommodate students. A second grant followed in 2006, which provided funds for construction of the "Commons" to expand students housing. Moreover, as a testament of Debbie's humility and connection to the SkIO community, all of the housing units are named for members of the staff who worked in the business office, shop and grounds. The one exception was for David Menzel who was our director for 23 years.

Debbie volunteered her time to the housing effort while she ran Rick's lab. She also managed the housing schedule and, I believe, she did a fair amount of cleaning when it was required at the last minute. Rick also shared this deep commitment to serve the Institute beyond just his research, and I'm sure he was helping Debbie clean sheets and other housing-related chores. Rick was always one of the most outspoken members of the faculty. During planning retreats and faculty meetings, his ideas and recommendations were the most constructive and generally carried the day. He was always prepared to argue his opinion, often in direct conflict with the views of the administration (which he became a part of during the latter part of his tenure), but always with the best interests of the institute in mind.

Rick, like Debbie, was also very "hands on" when it came to contributing to the Institute beyond his research. The best example of this was his efforts with regard to the planning and construction of the Institute's research vessel Savannah. During the late 1990 s, the Institute initiated the effort to acquire a vessel designed for coastal oceanographic research. Up until that time, the institute had relied on a converted fishing boat (R/ $\mathrm{V}$ Blue Fin), and although the boat was included in the UNOLS fleet, it was extremely limited in its capacity to accommodate multi-investigator research using modern technology. Its ability to operate for cruises of more than a week and it stability and safety were all problematic.

The first obstacle was The University System of Georgia, which had never funded the construction of a ship. Rick was Associate Director during this period and was engaged in the effort to convince the Chancellor's Office that they needed to think of this ship as a floating building, more in line with their idea of "a capital project." I think Rick originated that idea. Rick probably had more shipboard experience than any other member of the faculty did at the time, so he agreed to take on the job of working with the faculty to develop the research vessel's mission. He then worked with a marine architect to develop a design that fit that mission (including wave tank studies) on which an estimate of costs could be developed in preparation for a proposal for funding. This took an incredible amount time and attention away from his research, but Debbie had his back and his (and Debbie's) research productivity maintained about three publications a year, not to mention all his other commitments (education, panels, committees, etc.).

Ultimately, we received the funds for construction of the vessel and, again, Rick provided the administrative oversight of the construction and outfitting of the vessel. On May 25, 2001, the R/V Savannah was launched at the Washburn and Doughty shipyard in Booth Bay, Maine (Fig. 1, Debbie and Rick). The Savannah was designed specifically for coastal ocean research, and to this day, it remains as one of the busiest vessels in the UNOLS Fleet. 


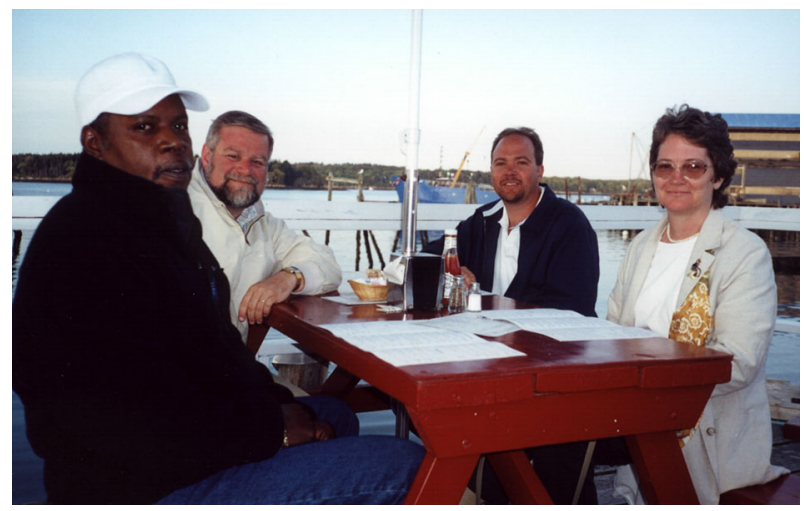

Fig. 1 Debbie (right), Rick (second from left) and two of the SkIO machine shop group at the R/V Savannah Christening

Rick served as Acting Director during the Institute's search for a permanent director during 2001. Somewhere along the way, Debbie and Rick formalized their relationship in marriage. This came at a time when their commitment needed to be formalized, although their devotion to each other was always solid, never wavering. In 2008, they decided it was time to smell the roses, retire and move to Washington where they both had ties. Their departure saddened us all, but the research at the Institute took the biggest hit. Rick was on top of his game and was a major contributor to all aspects of research at the institute. And we had to ultimately hire someone to maintain and manage the housing facilities which Debbie virtually singlehandedly created.

The Skidaway community is not the same without Debbie and Rick. They were and are a unique couple. The contrast in their personalities is probably why they were so effective as a team but also fun to be around. Rick had the laid-back Midwestern sort of personality where you could have a heated, but good-natured, discussion/debate and then go have a beer and forget who won the debate much less care. Debbie had a bit more of a West Coast "take no prisoners" personality and did not suffer fools. Underlying this personality, however, is an unassuming woman who serves others and cares about vulnerable people and animals. Rick and Debbie are two of the most humble, honest and smartest people I have known. Their combined intellect and work ethic has made them the formidable couple that they are and it is an honor to have worked with them for a couple of decades and to count them among my friends and colleagues.

\section{Contributions by Colleagues to this Special Issue}

In honor of their many contributions, we present this Special Issue titled "A Tribute to Rick and Debbie Jahnke: From Deep Sea Pore Water to Coastal Permeable SedimentsContributions that Cover the Oceans." There are nine papers from many of their international colleagues. These papers discuss various aspects of sediment geochemistry and element cycling that both Rick and Debbie specialized in and helped develop.

Oxygen dynamics and consumption are a major focus in sediment geochemistry. Oxygen consumption is tied to the decomposition of organic matter and its exchange across the water-sediment interface. Several papers in this issue use in situ techniques to 
investigate these processes. In deep sediments of the abyssal plain of the northeast Pacific Ocean, Smith et al. (2016) discuss changes in sediment community oxygen consumption and re-mineralization of sinking particulate organic carbon supply over a three-decade time series study. To better understand primary production and organic matter degradation through oxygen, Chipman et al. (2016) employ the eddy covariance method for the in situ determination of oxygen flux across the water sediment interface in shallow water sands of the Northeastern Gulf of Mexico. Using similar in situ methods, Reimers et al. (2016) provide new insights into the dynamics of benthic respiration by measuring oxygen exchange rates in mid-shelf sediments off the Oregon coast. Glud et al. (2016) also use these in situ and other methods to understand carbon mineralization and nutrient turnover as a result of oxygen uptake and exchange across the water sediment interface. Organisms influence element cycling across the water-sediment interface via bioturbation, which has two major components [bio-mixing (solid particle transport) and bio-irrigation (enhance solute transport)] that Van de Velde and Meysman (2016) describe with a reactive transport model to further our understanding of iron and sulfur cycling. Savidge et al. (2016) describe thermal fronts across this interface as a new thermal proxy to examine sediment-water exchange and provide a newly developed transport model to estimate the extent to which heat was transported by advection rather than conduction.

There are other processes that consume oxygen, and Dias et al. (2016) describe the abiotic production of reactive oxygen species such as superoxide and hydrogen peroxide via the reaction of aqueous $\mathrm{Fe}(\mathrm{II})$ with oxygen at the surface of roots of Spartina alterniflora, a salt marsh plant, leading to the formation of iron(III)(oxy)hydroxides precipitates on the roots.

The role of organic carbon in sediments is another major focus in sediment geochemistry. Chambers et al. (2016) describe an improved method coupling different techniques to recover dissolved organic matter for improving its compositional characterization. Lastly, Komoda et al. (2016) describe the recycling of organic matter at a boundary between the base of a hemipelagic mud section and the top of a turbiditic interval in the sediments of the Santa Monica Basin using $\Delta^{14} \mathrm{C}$ and $\delta^{13} \mathrm{C}$.

\section{References}

Bothner MH, Jahnke RA, Peterson ML, Carpenter R (1980) The rate of mercury loss from contaminated sediments. Geochim Cosmochim Acta 44:273-285

Boudreau BP, Huettel M, Forster S, Jahnke RA, McLachlan A, Middleburg JJ, Nielsen P, Sansone F, Taghon FG, Van Raaphorst W, Webster I, Weslawski JM, Wiberg P, Sundby B (2001) Permeable marine sediments: overturning an old paradigm. EOS Trans Am Geophys Union 82:133-136

Chambers LR, Ingall ED, Saad EM, Longo AF, Takeuchi M, Tang Y, Benitez-Nelson C, Haley ST, Dyhrman ST, Brandes J, Stubbins A (2016) Enhanced dissolved organic matter recovery from saltwater samples with electrodialysis. Aquat Geochem 22(5-6):555-572

Chipman L, Berg P, Heuttel M (2016) Benthic oxygen fluxes measured by eddy covariance in permeable Gulf of Mexico shallow-water sands. Aquat Geochem 22(5-6):529-554

Craven DB, Jahnke RA, Carlucci AF (1986) Fine scale vertical distribution of microbial biomass and activity in California Borderland sediments. Deep Sea Res 33:379-390

Dias DMC, Copeland JM, Milliken CL, Shi X, Ferry JL, Shaw TJ (2016) Production of reactive oxygen species in the rhizosphere of Spartina dominated salt marsh systems. Aquat Geochem 22(5-6):573-591

Glud RN, Berg P, Stahl H, Hume A, Larsen M, Bradleym DE, Cook PLM (2016) Benthic carbon mineralization and nutrient turnover in a scottish sea loch: an integrative in situ study. Aquat Geochem 22(5-6):443-467 
Ingall E, Jahnke R (1997) Influence of water column anoxia on the elemental fractionation of carbon and phosphorus during sediment diagenesis. Mar Geol 139:219-230

Jahnke RA (1984) The synthesis and solubility of carbonate fluorapatite. Am J Sci 284:58-78

Jahnke RA (1985) A model for microenvironments in deep sea sediments: formation and their effects on pore water profiles. Limnol Oceanogr 30:956-965

Jahnke RA (1988) A simple, reliable and inexpensive pore water sampler. Limnol Oceanogr 33:483-487

Jahnke RA (1996) The global ocean flux of particulate organic carbon: areal distribution and magnitude. Glob Biogeochem Cycles 10:71-88

Jahnke RA, Christiansen MB (1989) An in situ benthic experimental chamber instrument for seafloor studies. Deep Sea Res 36:625-637

Jahnke RA, Craven DB (1995) Quantifying the role of heterotrophic bacteria in the carbon cycle: a need for respiration rate measurements. Limnol Oceanogr 40:436-441

Jahnke DB, Jahnke RA (2008) Dynamics of seafloor processes: advances from benthic observing technologies. Oceanography 21:162-163

Jahnke RA, Heggie D, Emerson S, Grundmanis V (1982) Pore waters of the central Pacific Ocean: nutrient results. Earth Planet Sci Lett 61:233-256

Jahnke RA, Emerson SR, Cochran K, Hirschberg DJ (1986) Fine scale distributions of porosity and particulate excess ${ }^{210} \mathrm{~Pb}$, organic carbon and $\mathrm{CaCO}_{3}$ in surface sediments of the deep equatorial Pacific. Earth Planet Sci Lett 77:59-69

Jahnke RA, Reimers CE, Craven DB (1990) Intensification of recycling of organic matter at the sea floor near ocean margins. Nature 348(6296):50-54

Jahnke RA, Craven DB, Gaillard J-F (1994) The influence of organic matter diagenesis on $\mathrm{CaCO}_{3}$ dissolution at the deep sea floor. Geochim Cosmochim Acta 58:2799-2809

Jahnke RA, Alexander CR, Kostka JE (2003) Advective pore water input of nutrients to the Satilla River Estuary, Georgia, USA. Estuar Coast Shelf Sci 56:641-653

King SL, Froelich PN, Jahnke RA (2000) Early diagenesis of germanium in sediments of the Antarctic South Atlantic. Geochim Cosmochim Acta 64:1375-1390

Komoda T, Burdige DJ, Magen C, Li HL, Chanton JP (2016) Recycling of organic matter in the sediments of Santa Monica Basin, California Borderland. Aquat Geochem 22(5-6):593-618

Reimers CE, Özkan-Haller HT, Sanders RD, McCann-Grosvenor K, Chace PJ, Crowe SA (2016) The dynamics of benthic respiration at a mid-shelf station off oregon. Aquat Geochem 22(5-6):505-527

Savidge WB, Gargett A, Jahnke RA, Nelson JR, Savidge DK, Short RT, Voulgaris G (2008) Forcing and dynamics of seafloor-water column exchange on a broad continental shelf. Oceanography 21:179-184

Savidge WB, Wilson A, Woodward G (2016) Using a thermal proxy to examine sediment-water exchange in mid-continental shelf sandy sediments. Aquat Geochem 22(5-6):419-441

Shaw T, Gieskes JM, Jahnke RA (1990) Early diagenesis in differing depositional environments: the response of pore water transition metals. Geochim Cosmochim Acta 54:1233-1246

Smith KL, Carlucci AF, Jahnke RA, Craven DB (1987) Organic carbon mineralization in the Santa Catalina Basin: benthic boundary layer metabolism. Deep Sea Res Part A Oceanogr Res Pap 34:185-211

Smith KL, Huffard CL, Sherman AD, Ruhl HA (2016) Decadal change in sediment community oxygen consumption in the abyssal northeast Pacific. Aquat Geochem 22(5-6):401-417

Van de Velde S, Meysman FJR (2016) The influence of bioturbation on iron and sulphur cycling in marine sediments: a model analysis. Aquat Geochem 22(5-6):469-504

Weiss RF, Jahnke RA, Keeling CD (1982) Seasonal effects of temperature and salinity on the partial pressure of carbon dioxide in seawater. Nature 300:511-513 